\title{
High resolution remote sensing data application to assess parking space in urban area
}

\author{
R. Suharyadi and Iswari Nur Hidayati \\ Faculty of Geography, Universitas Gadjah Mada, Yogyakarta, Indonesia
}

Received: 2020-08-09 Accapted: 2020-12-03

Keywords:

Parking requirements; remote sensing;

urban areas

Correspondent email: suharyadir@ugm.ac.id

\begin{abstract}
The increase population in a large city such as Yogyakarta has caused an increase in the number of cars. The large number of cars created another problem of limited parking space in the city. Currently, there is a lack of a spatial approach to solve the problem of parking space. With the availability of highresolution remote sensing data, the business area in the city can be mapped accurately. This study aims to map the business zone in Yogyakarta City and to estimate the needs of parking space for trade, service, and education centers in Yogyakarta City using remote sensing imagery. The business zone really needs a parking area because many people as producers for loading goods and consumers buy at these stores. The method used to estimate the vehicle parking space requirement is a combination of field surveys and the interpretation of remote sensing images. The field survey was used to obtain the characteristics of the visitors, and the volume of filled parking space. Meanwhile, remote sensing imagery was used to obtain spatial data of land use. The parking requirements of commercial buildings are 2.25-3.15 spaces per $100 \mathrm{~m} 2$, offices are 1.0-1.60 spaces per $100 \mathrm{~m} 2$, hotels are 0.25-0.35 spaces for each sleeping room, theaters are 0.06 spaces for every seat, hospitals are 0.60 spaces for each bed, and schools are 0.10 space for every student. This paper demonstrated the use of remote sensing to solve urban vehicle problems, and such information can be used for city planning.
\end{abstract}

@2020 by the authors. Licensee Indonesian Journal of Geography, Indonesia.

The Creative Commons

Attribution(CC BY NC) licensehttps://creativecommons.org/licenses/by-nc/4.0/.

\section{Introduction}

In some developing countries, as well as in Indonesia, the urban area has grown explosively in recent decades, both in terms of population and built-up areas. On a global scale, population growth in urban areas shows a continuous rise with no signs of decline, indicating a constant rise over the next few decades (Suharyadi, 2011a). A general idea of high population growth in urban areas can be viewed from the increased number of urban areas with a population of more than 1 million. The population living in cities, high density places of at least 50,000 inhabitants, has more than doubled over the last 40 years, going from 1.5 billion in 1975 to 3.5 billion in 2015. OECD/European Commission, (2020) stated that almost half the world's population (48\%) lives in cities, a quarter live in rural areas (24\%), and the remaining people live in towns \& semi-dense areas (28\%) .

Transportation is very important in life. Economic development in all regions depends on transportation conditions that support access and transportation of goods. In addition, road transportation is the main mode of transportation in urban areas (Pojani \& Stead, 2015). Unfortunately, this aspect is closely related to environmental hazards and human health. This is due to transportation, especially pollution caused by motorized vehicle pollution. The increase in the number of private cars in urban areas is caused by good economic growth in an area (Stossel, Kissinger, \& Meir, 2017). The growth of vehicles is so fast that it is not being matched by the growth of road infrastructure.
This causes traffic jams. However, the increase in the number of vehicles is not accompanied by traffic management. The coordination between parking policies and traffic management gives an illustration that parking problems are not a minor problem and are an immediate problem to be solved. The number of people mobilizing with vehicles in urban areas has also increased sharply, as indicated by the growing number of vehicles in urban areas in Indonesia, i.e., over $10 \%$. According to Suharyadi (2011b), the national growth of infrastructure (new roads) in urban areas is relatively low at around $\pm 4 \%$, while the growth of transportation means is much higher, which is $\pm 11 \%$. The rapid growth of vehicles is the reflection of increased population mobility (Wang et al., 2020). Such growth will have a direct impact on the frequency of road utilization, including the use of parts of the roads for non-traffic activities. In recent years, the majority of the roads in urban areas have been used for parking of vehicles, especially for business activities and services (Dowling et al., 2017). These conditions decrease the functions of roads as an infrastructure that provides traffic services.

Various studies have been carried out for parking modeling with different conditions and scenarios taking into account parking conditions (Wang et al., 2019). Behavior of residents to park as close as possible with the aim of causing parking to pile up at specific locations such as close to shopping centers, stations, bus stops, or eating places located 
on the side of the road. The number of parking spaces along the main road is very influential in traffic, especially during pick hour (Fadeyev, 2017). Parking that uses the sidewalk, which is devoted to pedestrians, also disrupts pedestrian flexibility. At the strategic planning level, it is essential to evaluate existing parking facilities to develop service levels to make better plans and operations in the future (Sweet \& Ferguson, 2019). Parking performance evaluation approach by considering parking characteristics and types of land use becomes a crucial part of this research. In addition to this, the type of land use that affects parking is also an input in determining parking policies. The parking policy determines the vital role in the development of a well-organized traffic system to improve road users' comfort. A well-structured parking policy contributes to reducing emissions, better city design, and smooth traffic. Parking policies must be integrated with local and national policies.

A similar condition also occurs in Yogyakarta City, where several roads are used for non-traffic activities, causing an increase in traffic volume and a decrease in the level of service. The decreased level of service is mostly because the utilization of the roads is not by their functions. Such improper use is triggered by commercial buildings, government offices, and education centers that do not provide parking spaces, nor do they provide ones with the capacity to meet the needs of the visitors. In order to anticipate the paucity of parking space in these facilities, a guideline becomes necessary in determining the required parking space for each type of facility following their locations.

Despite the existence of many plans for managing population growth in urban areas, a breakthrough is preferable in the acquisition and management of spatial data (Al-Turjman \& Malekloo, 2019). The managers of urban areas should be able to make a breakthrough in obtaining, managing, and processing spatial data of their areas. The spatial data acquisition technologies that meet these criteria are remote sensing imagery, which provides a source of spatial data, and Geographic Information Systems (GIS), which processes and analyzes spatial data. Some studies on urban parking space requirement has been conducted intensively in developed countries (Sweet \& Ferguson, 2019). The development of a new operational method and GISbased algorithm that better represents the space-time characteristics of urban opportunities, including access to the parking lot, has been considered in urban planning and management (Bendouda, 2018). Some studies have used advance GIS approaches to parking space real availability time (Aliniai et al., 2015) but there were applied in a wellplanned urban area. Therefore, this current study becomes a preliminary identification of robust RS and GIS methods to efficiently estimate and map the space and location of parking lots. In the last few years, the decreased level of service provided by roads as an infrastructure has been felt by the people who travel into Yogyakarta City during rush hours in the morning, afternoon, and evening. This condition worst during the holiday seasons, mainly because Yogyakarta is a cultural city that has been a destination for both domestic and international tourists.

Evaluating future parking requirements is very difficult due to an increase in the number of private cars, population growth, development in the commercial era, and an increase in shopping areas. The use of GIS for parking analysis is very useful as a data provider. There have been many roles of GIS for transportation and traffic planning. GIS can help to map, analyze, and map parking spots. Using a GIS makes it possible to logically and precisely data about individual parking spaces. The ability to sort different characteristics of a parking lot by location and to view these characteristics on a map makes GIS an invaluable tool. The cause of traffic congestion on several roads in Yogyakarta City is likely caused by the third factor, namely the addition of traffic volume and, at the same time, the utilization of the majority of the road for non-traffic activities, particularly for parking vehicles. Most of commercial centers and education facilities do not provide parking spaces for their visitors. Meanwhile, the other facilities provide parking lots with limited space, which is not under the needs of their visitors. Nevertheless, the Government of Yogyakarta City has established several efforts to prevent traffic congestion from getting worse, such as one-way engineering roads (e.g., Jalan Prof. Dr. Ir. Herman Yohanes and Jalan C. Simanjuntak). Traffic engineering aims to improve the service provided by roads to avoid traffic jams (Zhang \& Qian, 2019). Aside from the traffic, as mentioned earlier engineering, the Government of Yogyakarta City are urged to issue regulations that enforce the provision of adequate parking facilities in commercial buildings, offices, and education centers. The types of economic and service-oriented activities were selected based on those that pulled the most traffics heading to Yogyakarta City. According to Wirawan (2014), the pulling factors of high traffic in urban areas in Yogyakarta come from service provisions, commercial activities, education, and offices. In this study, the estimation of parking requirements focuses on service provision buildings, commercial buildings, education centers, and offices. The land uses that might prompt and contain tourist attractions and sporting facilities were not included in the estimation because, generally, they have had adequate parking facilities. Based on the afore mentioned formulates the following questions (a) How is the zonation of business activities in Yogyakarta City based on the uniformity of public transport services, traffic management, and the relative location? Furthermore, (b) How is a dataset containing the parking requirements of service provision buildings, commercial buildings, education centers, and offices in Yogyakarta City acquired?

\section{The Methods}

The data used in this study include are the spatial data of the business objects: i.e., service provision buildings, commercial buildings, education centers, and office, (2) The characteristics of the business objects: i.e., relative location, building size, number of facilities, and (3) The characteristics of the visitors of service provision buildings, commercial buildings, education centers, and offices. The specification of data can be seen in Table 1 .

The parking requirements were estimated using an empirical approach, which is through a study of the characteristics of business types, the number of parking lot users, and the peak hours of parking activities in several service provision buildings, commercial buildings, education centers, and offices in Yogyakarta City. The spatial data were obtained from visual interpretation remote sensing images with a very high spatial resolution. The benefit of highresolution remote sensing is that it provides spatial data that is used for land extraction which allows it to be used for 
Table 1. Types and Sources of Research Data

\begin{tabular}{ll}
\hline Types of Data & Sources of Data \\
\hline Spatial data & Remote sensing images and the Indonesian Topographic Map (RBI) 1: 25,000 \\
The characteristics of the business objects & $\begin{array}{l}\text { Remote sensing images and field survey } \\
\text { The characteristics of the visitors }\end{array}$ \\
\hline
\end{tabular}

parking lots. In addition, data analysis for the parameters used for parking analysis. The approach used is a visual analysis of land use from remote sensing data. The land use data collected is the various types of land use that are around the highway or locations that have open space that can be used for parking areas. The role of GIS is used to estimate and calculate the decision on the number of areas that can be used for parking areas. This research also relied on field surveys to obtain primary data related to the characteristics of parking spaces and vehicles, including the volume of parking spaces and the peak hours of parking activities in various types of business. This research used GIS to integrate spatial data extraction from remote sensing images and attribute data acquired from field surveys. The parking policy determines the critical role in the development of a well-organized traffic system to improve road users' comfort. A well-structured parking policy contributes to reducing emissions, better city design, and smooth traffic. Parking policies must be integrated with local and national policies. The importance of better parking to improve the quality of life and optimize the time spent.

\section{Business Zonation}

Quickbird images were used to provide spatial data for mapping the business objects, i.e., service provision buildings, commercial buildings, education centers, and offices in Yogyakarta City (Lung et al., 2013). The spatial data were extracted using visual interpretation on remote sensing images. The business objects analyzed in this study include service provision buildings (hotels, cinemas, and hospitals), commercial buildings (shops, complex of shops, traditional markets, supermarkets, and shophouses), offices, and education centers (schools and college campuses). In order to meet the standard geometric accuracy for mapping the business the Quickbird images, as the source of spatial data, were geometrically corrected using the1: 25,000 Indonesian Base Map (i.e., reference map). In order to improve the spatial data acquired from visual interpretation on Quickbird images, these data were selected using a purposive sampling technique for field check. Geography is being handed an increasing importance for its key role in the understanding of the success of a business (Ramadani et al., 2018). The zonation of business object was obtained by combining the spatial maps of the Public Transportation Service, Traffic Management, and Relative Location. The maps of the Public Transportation Service and Traffic Management were obtained from secondary data, while the Relative Location map was generated from analyzing the 1: 25,000 Indonesian Base Map.

\section{The Estimation of Parking Space Requirements}

The parking space requirements of each business object are influenced by the characteristics of the visitors, including the number of visitors and the means of transportation. Theoretically, visitors coming to business objects require sample parking space. In terms of means of transportation, visitors driving in with their private vehicles require a broader parking space than those coming in with public transports. Theoretically, the parking space requirements are affected by land characteristics, namely:

- The characteristics of the standard means of transportation. The parking space requirement in urban areas with adequate public transportation services is relatively low. On the contrary, urban areas with poor public transportation have a high demand for parking space. Excellent public transportation services are determined not only by the quality of the facilities (the condition of the public vehicles) but also by other factors, such as route, timeline, cost, and safety.

- Traffic management. The prohibition of certain types of vehicles on the roads leading to a lower, even, zero parking space requirement

- Relative location. The parking space requirements of each type of land use in the city center and the suburbs show differences.

\section{Working Procedures}

The parking space requirements were estimated using remote sensing images with the following stages and more detail can be seen in Figure 1:

A. Mapping the land utilization in Yogyakarta City, particularly the service provision buildings, commercial buildings, education centers, and offices. The land use was mapped using spatial data acquired through visual presentation on Quickbird remote sensing images and field surveys. The spatial data were classified into service provision (hospitals, hotels, theaters) buildings, commercial buildings, education centers (schools), and offices.

B. Determining the business zone based on uniformity in the characteristics of the conventional means of transportation, traffic management, and relative location. The aforementioned spatial data acted as an input in providing map of business zone, which divided Yogyakarta City into four classes, namely: Zone 1 (city center with better public transportation services), Zone 2 (city center with poor public transportation services), Zone 3 (suburb with excellent public transportation service), Zone 4 (suburb with poor public transportation services). 
B. Creating an inventory of the characteristics of business objects (interpreting the floor area of the commercial buildings and offices; counting the number of rooms in the hotels, the number of beds in the hospitals, the number of seats in the theaters, and the number of students in the schools). The inventory of the characteristics of business objects was obtained through a stratified sampling technique in each business zone. This parameter uses secondary data because this parameter cannot be extracted directly from remote sensing data.

Creating an inventory of the characteristics of visitors by counting the number of vehicles and visitors at peak hours in each sampled business type from field data collection and statistic data. The inventory of the characteristics of visitors was created to acquire the following data:

A. The number of visitors and the means of transportation they use.

B. The number of vehicles parked during peak hours.

Estimating the parking space requirement in each business object: service provision building, commercial building, education center, and office using statistical analysis, i.e., a simple linear regression between the characteristics of the business object and the number of vehicles parked in it at peak hours.

Calculate parking capacity on the road using formula

$$
k p j=\frac{(p j r-p j p)}{k b}
$$

kpj : : parking capacity for each road section

pjr : length of road section $(\mathrm{m})$

Pjp : length of road that is not as a parking location (m)

$\mathrm{Kb} \quad$ : Parking vehicle needed

\section{Result and Discussion}

Visual interpretation includes the steps of land use analysis and road network mapping using GIS data. The use of Quickbird to manage parking data is very important. Data can be collected in detail. Quickbird's spatial resolution can provide information on parking parameters such as road width, road type, road conditions, and land use. Vîlcea \& Șoșea (2020) also stated visual data interpretation is the most important thing for extracting data from remote sensing imagery. The combination of the spectral channels that the image has, namely the red, green, and blue bands provides an RGB combination that matches the original color in the field. High resolution extraction of land use type information minimizes errors in interpretation tests. In this case, the resulting interpretation accuracy is $92 \%$ in accordance with the specified minimum requirements. This is as required by Anderson et al., (1976) to test the accuracy of land use mapping. The analysis was carried out in accordance with the formulation of the problem in the study, namely analysis on parking characteristics, parking requirements model and parking requirements standards. From the accumulated results of vehicle parking, data analysis to calculate accumulation average parking (vehicle) that occurs at a shopping center. Accumulated results the parking rate is used as a fixed variable in the analysis parking demand modeling.

\section{Business Zonation}

Based on analysis of the remote sensing data, business zonation is an attempt to sort out the research area into several areas that are assumed to consist of uniform characteristics, namely means of public transportation service, traffic management, and relative location (Dogru et al., 2017). Areas with the same characteristics are assumed to have the same parking space requirement for the same type

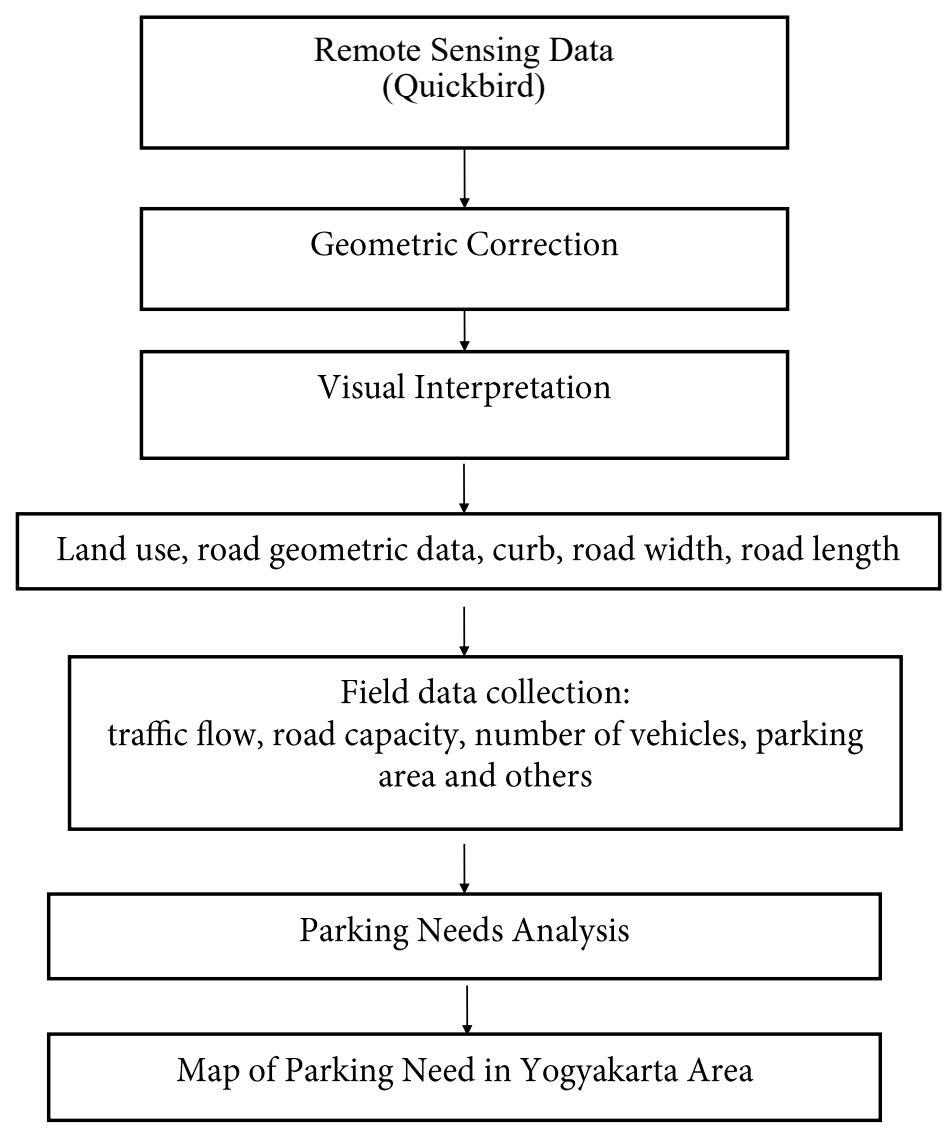

Figure 1. Parking Need Assessment Flow Chart 
of business. In other words, the parking space requirement for the same type of business in this zone is different from the other business zones. Business zonation was determined by combining three sets of spatial data, namely: the characteristics of public transportation services, traffic management, and relative location. Accordingly, the business location in Yogyakarta City can be divided into four classes, namely: Zone 1 (city center with excellent public transportation services), Zone 2 (city center with poor public transportation services), Zone 3 (suburb with excellent public transportation service), and Zone 4 (suburb with poor public transportation services).

As presented in the Map of Business Zone, Zone 1 is distributed within the city center and the areas adjacent to the main streets in Yogyakarta City. Moreover, it dominates the city. Zone 2 is distributed in several areas around the city center with inadequate public transportation services. Meanwhile, Zone 3 and Zone 4 are mainly distributed in the northwest and southeast parts of Yogyakarta. The overview of business zonation is presented in Figure 2.

\section{Parking Demand Assessment}

In this study, the parking space requirement was calculated based on the characteristics of the type of business object, the location of the business object, and the characteristics of visitors in each business zone. The characteristics of the type of business were derived from visual interpretation of remote sensing images and field surveys. Meanwhile, the business zonation is the result of analysis on the maps of public transportation services, traffic management, and relative location. The characteristics of visitors were acquired from field observations. The size or the unit used to determine the parking space requirement is parking space (or space). It measures the active area for parking vehicles, which in this case are a passenger car, bus or truck, and motorcycle that are parked on the street, in a parking area, or inside a parking building. It considers the extent of space for moving conveniently and opening the vehicle's doors widely. If the unit 'space' is used without any specific explanation, it is intended for passenger cars. In this study, the dimensions of the parking space requirements refer to the guidelines of the Directorate General of Land Transportation (1998), the dimension of space (Satuan Ruang Parkir) for passenger cars is $3.0 \times 5.0 \mathrm{~m}^{2}$, while the space for motorcycles is $0.75 \times 2.0 \mathrm{~m}^{2}$. The business objects that need parking space are those included in service provision buildings, commercial buildings, education centers, and offices. The calculation of parking space demand was performed at peak hours. The peak hours of service provision buildings are as follows: hotels are at 19:00-20:00, theaters are at 19:00-20:00, and hospitals are at 16:00-17:00. Meanwhile, the peak hours of commercial buildings are as follows: traditional markets are at 06:00-07:00, and the stores are from 13:00-14:00. The peak hours of education centers and offices are at 08:00-09:00 and 10:00-11:00, respectively.

In this study, the empirical approach was carried out by observing some business objects that were distributed evenly in each business zone. In other words, the samples distributed in Zones 1, 2, 3, and 4 were selected based on the parameter 'relative location'. The business objects selected for estimating the parking space requirement are only the types of businesses that have parking facilities because calculating the estimates of parking requirements for business objects with no parking facilities is difficult. The distribution of

Table 2. The estimates of parking requirements for commercial buildings

\begin{tabular}{ccccc}
\hline Zones & Floor area $\left(\mathrm{m}^{2}\right)$ & Visitor (Cars) & Visitor (Motorcycles) & Parking requirements \\
\hline I & 5,350 & 372 & 76 & 3.2 \\
II & 1,290 & 137 & 6 & 3.1 \\
III & 870 & 27 & 8 & 1.6 \\
IV & 4,158 & 437 & 13 & 2.9 \\
\hline
\end{tabular}

Table 2 shows that the required parking spaces for motorcycles in commercial buildings in the city center and the suburbs are different. The commercial buildings at the city center require a larger parking space than the ones in the suburbs. The estimates of parking requirements for offices are presented in Table 3 below. This table shows that the offices located in the suburbs require a slightly larger parking space than the ones in the city center.

Table 3. The estimates of parking requirements for offices

\begin{tabular}{ccccc}
\hline \multirow{2}{*}{ Zones } & Floor area $\left(\mathrm{m}^{2}\right)$ & Visitors & Parking requirements $\left(\right.$ spaces per $\left.100 \mathrm{~m}^{2}\right)$ \\
\cline { 3 - 5 } & - & Motorcycles & Cars & - \\
\hline I & 210 & - & - & 1.0 \\
II & 1,479 & 8 & 0 & 1.6 \\
III & - & 75 & 5 & - \\
IV & - & & & - \\
\hline
\end{tabular}




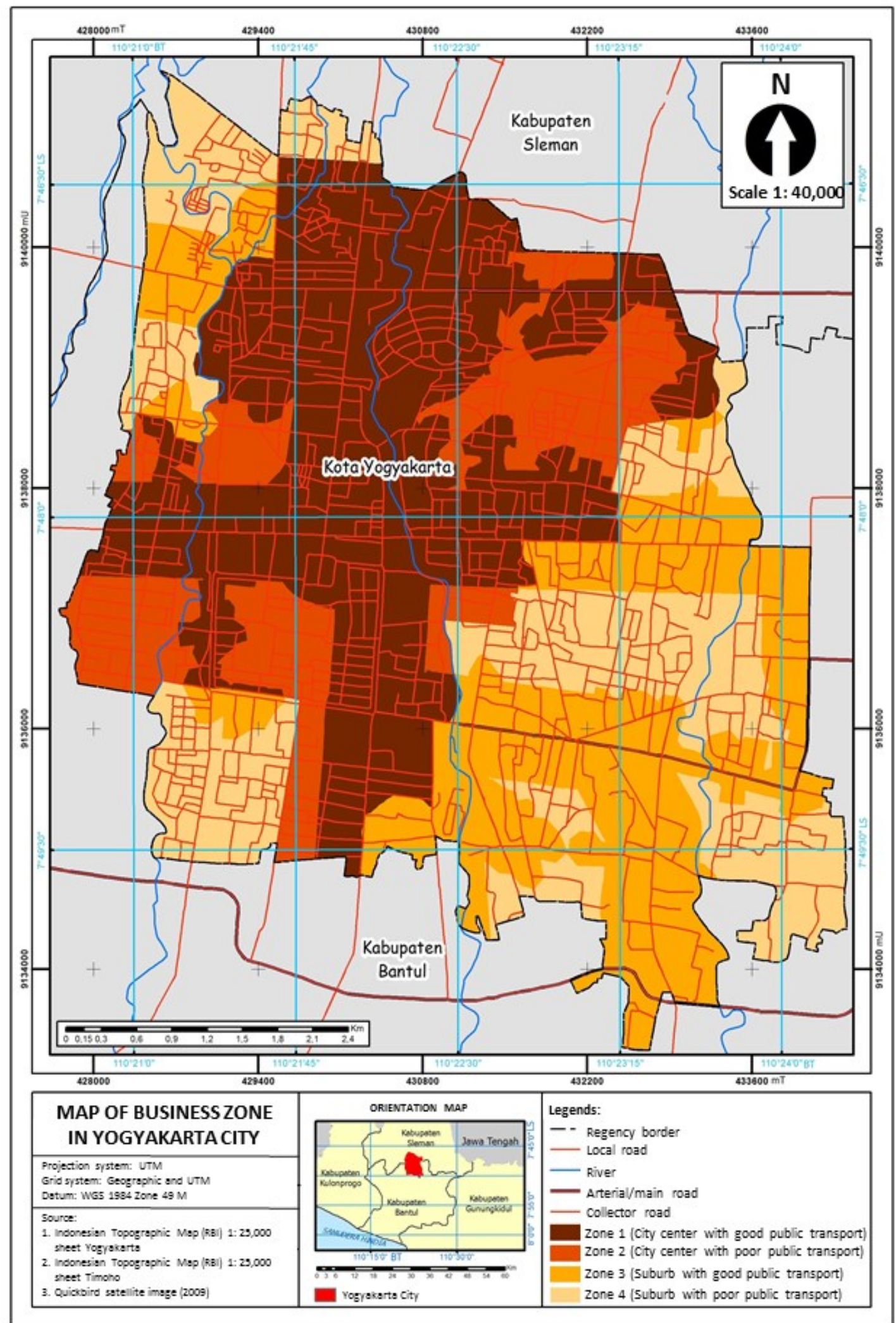

Figure 2. Map of business zone in Yogyakarta City

observation points is depicted in the Map of Land Use and Point Samples (Figure 3). The estimation results for commercial buildings are summarized in Table 2 .

The estimates of parking space requirements for hotels were based on the characteristics of visitors and the number of rooms. The samples included in this research are hotels located in each zone (relative location). The calculation results are summarized in Table 4 . This table shows that the parking requirements for hotels in the suburbs are more substantial than in the city center although with small differences. The parking requirements for hotels at the city center are 0.3 spaces per room, while the ones in the suburbs are 0.4 spaces per room.

The estimates of parking requirement for theater was calculated on a single because there is only one theater operating in separated from more prominent commercial 


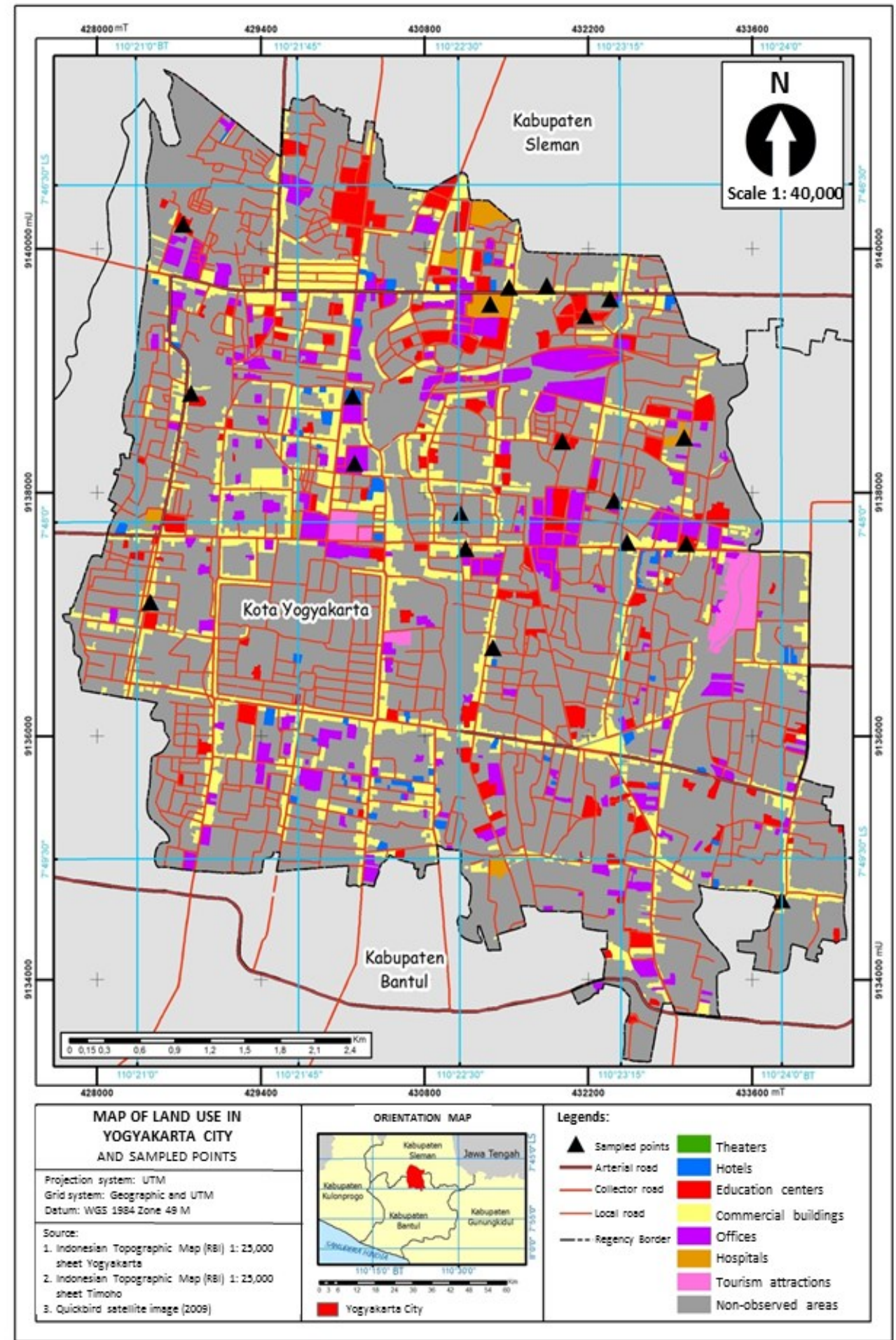

Figure 3. Map of land-use type of Yogyakarta City

Tabel 4. The estimates of parking requirements for hotels

\begin{tabular}{ccccc}
\hline Zones & Floor area $\left(\mathrm{m}^{2}\right)$ & \multicolumn{2}{c}{ Visitors } & $\begin{array}{c}\text { Parking requirements } \\
\text { (spaces per room) }\end{array}$ \\
\cline { 3 - 4 } & & Motorcycles & Cars & 0.3 \\
I & 44 & 13 & 4 & 0.2 \\
II & 141 & 72 & 27 & 0.3 \\
III & 101 & 5 & 17 & 0.4 \\
IV & 223 & 58 & 45 & \\
\hline
\end{tabular}


buildings regularly. Most of the existing theaters are located at the shopping centers. Based on calculations, the parking requirement for theaters is 0.06 spaces per seat, as seen in Table 5.

The parking requirement for hospitals was calculated based on field observation in two hospitals. The parking requirements for hospitals at the city center are the same as the ones in the suburbs, i.e., 0.60 spaces per bed. Table 6 below presents the space required for parking vehicles in the hospitals.

There are many areas occupied by education centers or schools in Yogyakarta City. The parking space requirements for schools in all zones are relatively similar, indicating no significant differences between the parking space requirements at schools at the city center and schools in the suburbs 0.1 spaces per pupil (student). Table 7 shows the data for estimating the parking space requirements for schools in Yogyakarta City.

The calculations of parking requirements in each business object existing in Yogyakarta City are summarized in Table 8. The results show that the parking requirements in this city are lower than the standard parking requirements determined by the government. For example, the parking requirements for commercial buildings are 3.1 spaces per 100 $\mathrm{m}^{2}$ at the city center and down to 2.25 spaces per $100 \mathrm{~m}^{2}$ in the suburbs, while the standards set by the government are between $3.5-7.5$ spaces per $100 \mathrm{~m}^{2}$. The same case applies to parking requirements for offices, service provision buildings, and education centers. Even though the figure that represents the parking space requirements in Yogyakarta City is lower than the standards set by the government, field observations

Table 5. The estimates of parking requirements for theaters

\begin{tabular}{ccccc}
\hline \multirow{2}{*}{ Zones } & & \multicolumn{2}{c}{ Visitors } & Parking requirements \\
(spaces per bed $)$
\end{tabular}

Source: Data Analysis (2014)

Table 6. The estimates of parking requirements for hospitals

\begin{tabular}{|c|c|c|c|c|}
\hline \multirow{2}{*}{ Zones } & \multirow{2}{*}{ Floor area $\left(\mathrm{m}^{2}\right)$} & \multicolumn{2}{|c|}{ Visitors } & \multirow{2}{*}{$\begin{array}{l}\text { Parking requirements } \\
\text { (spaces per seat) }\end{array}$} \\
\hline & & Motorcycles & Cars & \\
\hline I & 1,338 & 190 & 32 & 0.06 \\
\hline II & - & - & - & - \\
\hline III & - & - & - & - \\
\hline IV & - & - & - & - \\
\hline
\end{tabular}

Source: Data Analysis (2014)

Table 7. The estimates of parking requirements for schools

\begin{tabular}{ccccc}
\hline & & \multicolumn{2}{c}{ Visitors } & Parking requirements \\
Zones & Floor area $\left(\mathrm{m}^{2}\right)$ & Cars & \\
\cline { 3 - 5 } & & Motorcycles & 24 & 0.1 \\
\hline I & 2,724 & 671 & 0 & 0.1 \\
II & 698 & 369 & 13 & 0.1 \\
III & 1,669 & 307 & 0 & 0.1 \\
\hline
\end{tabular}


Table 8. The estimates of parking requirements in Yogyakarta City

Types of Business (Land use)
Parking requirement

(spaces per $100 \mathrm{~m}^{2}$ )
Parking requirement units for passenger cars

\begin{tabular}{lcl}
\hline Commercial buildings & 2.253 .15 & spaces per $100 \mathrm{~m}^{2}$ floor area \\
Offices & 1.001 .60 & spaces per $100 \mathrm{~m}^{2}$ floor area \\
Hotels & 0.250 .35 & spaces per room \\
Theaters & 0.06 & spaces per seat \\
Hospitals & 0.60 & spaces per bed \\
Schools & 0.10 & spaces per student \\
\hline
\end{tabular}

Source: Data Analysis (2014)

show that many vehicles are still parked on the roads (street parking). This case is caused by the capacity of the available parking facilities that are below the existing parking requirements.

Remote sensing for parking spaces can be a reference in terms of data extraction, accuracy testing, and optimal utilization of remote sensing data. The simple extraction method can be applied by further researchers. This method can be used as an alternative for selecting a parking space based on remote sensing data.

\section{Conclusion}

Yogyakarta City can be divided into four zones, namely: Zone 1 (city center with excellent public transportation services), Zone 2 (city center with poor public transportation services), Zone 3 (suburb with excellent public transportation service), and Zone 4 (suburb with poor public transportation services). Based on the calculation on each business object existing in Yogyakarta City, the parking requirements for commercial buildings $2.25-3.15$ spaces per $100 \mathrm{~m}^{2}$, offices are $1.0-1.60$ spaces per $100 \mathrm{~m}^{2}$, hotels are $0.25-0.35$ spaces per room, theaters are 0.06 spaces per seat, hospitals are 0.60 spaces per bed, and schools are 0.10 spaces per student. The parking requirements of Yogyakarta City are averagely lower than the standards set by the Indonesian government. There are no significant differences in parking requirements in all business zones in Yogyakarta City, which means that the needs of parking spaces in the city center and the suburbs are similar or slightly different.

\section{References}

Al-Turjman, F., \& Malekloo, A. (2019). Smart parking in IoTenabled cities: A survey. Sustainable Cities and Society, 49 (December 2018). https://doi.org/10.1016/j.scs.2019.101608

Aliniai, K., Yarahmadi, A., Zarin, J. Z., Yarahmadi, H., \& Lak, S. B. (2015). Parking Lot Site Selection: An Opening Gate Towards Sustainable GIS-based Urban Traffic Management. Journal of the Indian Society of Remote Sensing, 43(4), 801-813. https:// doi.org/10.1007/s12524-014-0415-3

Anderson, J. R., Hardy, E. E., \& Roach, J. T. (1976). A Land Use and Land Cover Classification System for Use with Remote Sensor Data.

Bendouda, M. (2018). Urban Road Network Extraction from Remote Sensing Images Using an Improved $\mathrm{F}$ * Algorithm. Journal of the Indian Society of Remote Sensing, 46(7), 1053-1060. https://doi.org/10.1007/s12524-018-0773-3
Direktorat Jenderal Perhubungan Darat. (1998). Pedoman Perencanaan dan Pengoperasian Fasilitas Parkir. Jakarta.

Dogru, A., Malaitham, S., Okamura, M., Fukuda, A., \& Fukuda, T. (2017). Parking Management Policies Based on Behavior Analysis at Fatih District in Istanbul, Turkey. Transportation Research Procedia, 25, 5205-5219. https:// doi.org/10.1016/j.trpro.2018.02.048

Dowling, C., Fiez, T., Ratliff, L., \& Zhang, B. (2017). How Much Urban Traffic is Searching for Parking? Simulating Curbside Parking as a Network of Finite Capacity Queues, (February). Retrieved from http://arxiv.org/abs/1702.06156

Fadeyev, D. (2017). Method for Evaluating Economic Efficiency of Parking Management Tools. Transportation Research Procedia, 20(September 2016), 193-199. https:// doi.org/10.1016/j.trpro.2017.01.050

Lung, T., Lübker, T., Ngochoch, J. K., \& Schaab, G. (2013). Human population distribution modelling at regional level using very high resolution satellite imagery. Applied Geography, 41, 36-45. https://doi.org/10.1016/j.apgeog.2013.03.002

OECD/European Commission. (2020). Cities in the World: A new perspective on urbanisation. OECD Urban Studies, 171. Retrieved from https://www.oecd-ilibrary.org/urban-ruraland-regional-development/cities-in-the-world_d0efcbda-en

Pojani, D., \& Stead, D. (2015). Sustainable urban transport in the developing world: Beyond megacities. Sustainability (Switzerland), 7(6), 7784-7805. https://doi.org/10.3390/ su7067784

Ramadani, V., Zendeli, D., Gerguri-Rashiti, S., \& Dana, L. P. (2018). Impact of geomarketing and location determinants on business development and decision making. Competitiveness Review, 28(1), 98-120. https:// doi.org/10.1108/CR-12-2016-0081

Stossel, Z., Kissinger, M., \& Meir, A. (2017). Modeling the Contribution of Existing and Potential Measures to Urban Sustainability Using the Urban Biophysical Sustainability Index (UBSI). Ecological Economics, 139, 1-8. https:// doi.org/10.1016/j.ecolecon.2017.03.039

Suharyadi, R. (2011a). Hybrid Interpretation of medium spatial resolution satellite imagery for urban study in building densification area (the case of Yogyakarta urban area. Gadjah Mada University.

Suharyadi, R. (2011b). Interpretasi hibrida citra satelit resolusi spasial menengah untuk kajian densifikasi bangunan daerah perkotaan (kasus daerah perkotaan Yogyakarta. Universitas Gadjah Mada.

Sweet, M. N., \& Ferguson, M. R. (2019). Parking demand management in a relatively uncongested university setting. Case Studies on Transport Policy, 7(2), 453-462. https:// doi.org/10.1016/j.cstp.2019.01.008

Text, F. (2020). Construction Of Parking Shed At 220 Kv Gis Substation Wazirpur . [ Tender documents:, 1-2. 
Transportation, D. G. of L. (1998). Guidelines for planning and operating parking facilities. Jakarta: Directorate General of Land Transportation.

Vîlcea, C., \& Șoșea, C. (2020). A GIS-based analysis of the urban green space accessibility in Craiova city, Romania. Geografisk Tidsskrift - Danish Journal of Geography , 120(1), 19-34. https://doi.org/10.1080/00167223.2020.1766365

Wang, F., Fan, W., Lin, X., Liu, J., \& Ye, X. (2020). Does population mobility contribute to urbanization convergence? Empirical evidence from three major urban agglomerations in China. Sustainability (Switzerland), 12(2), 1-20. https:// doi.org/10.3390/su12020458
Wang, P., Guan, H., \& Liu, P. (2019). Modeling and solving the optimal allocation-pricing of public parking resources problem in urban-scale network. Transportation Research Part B: Methodological, (xxxx). https://doi.org/10.1016/ j.trb.2019.03.003

Wirawan, H. . (2014). Use of Data Remote Sensing and Geographic Information System for Assessment Services Bus Stop Trans Jogja in Yogyakarta Urban region. Gadjah Mada University.

Zhang, P., \& Qian, Z. (Sean). (2019). Managing traffic with raffles. Transportation Research Part C: Emerging Technologies, 107 (September), 490-509. https://doi.org/10.1016/ j.trc.2019.09.002 